\title{
IMPROVING PRODUCTION TEXTILE TAPES ON NEEDLE NARROW WEAVE MACHINES FOR SUITABLE ENDUSE.
}

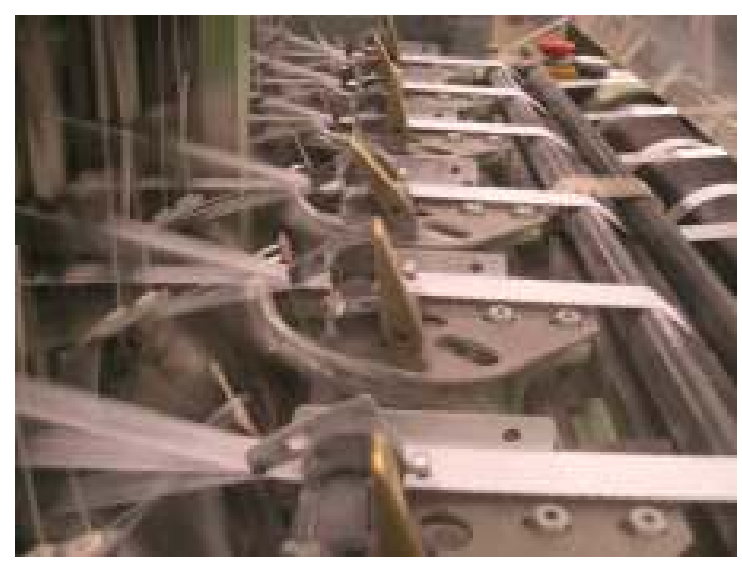

by

Dr. Sayed Takey Mohamed Abd Elmaksoud Lecture in Department of Textile Industrial Faculty of Industrial Education Suez Canal University

PROF.ASS.Ashraf Abd Elfatah Mostafa Prof.ass. In Department of Art Education Faculty of Specific Education El-Mansoura University.

مجلة بحوث التربية النوعية - جامعة المنصورة

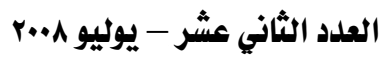


ב Improving Production Textile Tapes On Needle Narrow Weave Machines $\overline{=}$ 


\title{
Improving Production Textile Tapes On Needle Narrow Weave Machines For Suitable Enduse
}

PROF.ASS.Ashraf Abd Elfatah Mostafa

\begin{abstract}
Finally, the weft delivery of the RIEMCHENTRANSPORT was replaced by FOUMISSEUR.

In order to find a solution of this problem is investigating the factors affecting the width fabric in the direction of warp and weft. The study of the weft direction has a significant impact on this characteristic, namely weft yarn tension and the weft yarn length in weft feeder.

The methodology of this research depends on experimental and analytical approach. It is found that there exists an inverse relationship of weft yarn tension and direct relationship of weft delivery length with tape width. Moreover there is an inverse relationship between warp yarn tension and tape width.

This research involves the study of the problem that exists in most of the factories, which produce narrow fabrics, especially on the Needle Narrow Weave Machines (NFRQ). This is problem that the width fluctuation for these fabrics. This sector is considered one of the most important sectors of industrial fabric because of its multiple uses that affect industrial economy, whether linked to the textile or other industries. These tapes are used in the manufacture of medical bandages, normal or adhesive, apparel requirements of elastic tape, tapes of the process of decorative embellishment clothing or other uses like special types of electric cables and so on.
\end{abstract}


يعنى هذا البحث بلدراسـة مشكلة موجـودة فى معظم المصانع التي تقوم بإنتاج الأقهشـة ذات

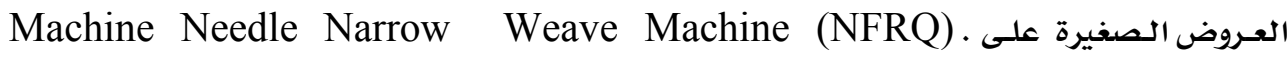

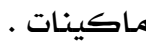

وهـذه المشكلة هـى تذبـذب عـروض الأثـرطة. ولتحسـين إنتاجهـا أمكن التغلـب على العيـوب

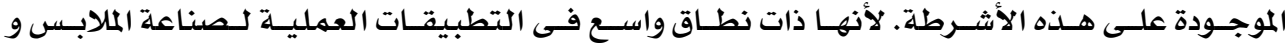
النسيجيات بصفة عامـة.

وهذا المجال يعتبر واحد مـن أهم المجالات الصناعية لإنتاج الأقمشة لما له من استخدامات

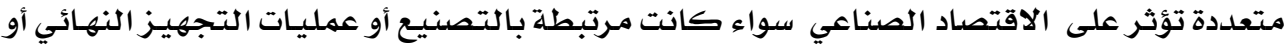
صناعة مستلزمات المالابس.

ومحاولة إيجاد حل هذه المثكلة وذلك عن طريق دراسـة بعض العوامل المؤثرة على خاصية

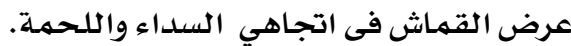

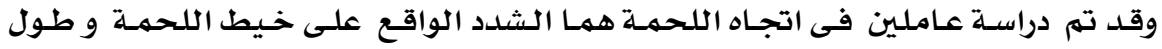

اللحمة المخزن على جهاز المغذى. وبالنسبـة لاتجاه السداء تم دراسة متوسط الشدد الواقع على خيوط

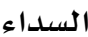

وقد تم التوصل إلى إيجاد علاقة عكسية بين عرض الشريط والشدد في اتجـاه اللحمهـة وقد

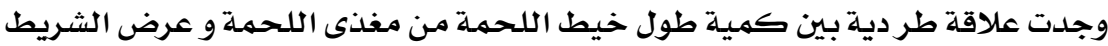

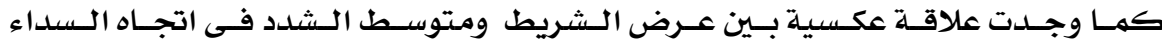

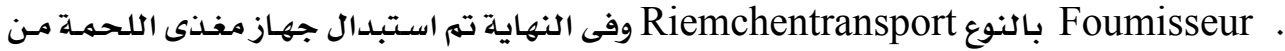
النوع لما له من مميزات إنتاجية أدت إلى التغلب على العيوب تذبذب عروض الأشرطة والعهل على ثبات

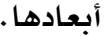




\section{1- INTRODUCTION}

Any fabric made by interlacing fibres or yarns which( in the U.K.) does not exceed $45 \mathrm{~cm}$ (18 in) in width. In the U.S., and for the purpose of the Tariff Code in the E.E.C., The upper limit of width is $30 \mathrm{~cm}$. A characteristic of a narrow fabric is that its edges are an essential feature(1).

Narrow fabrics are one of the most important areas in the fabric industries. To survive in an extremely competitive market, for some time now textile companies in the industrialized nations have been looking for niche products with high levels of added value. Numerous enterprises see technical textiles as being of strategic significance with regard to their existing and future markets. Moreover, technical textiles are becoming increasingly vital in a whole range of applications. These developments apply equally to the field of narrow fabrics. Apart from the classical readyto-wear clothing and household textiles segments, the technical textiles area is gaining in strategic importance for many companies.

And the width of the narrow fabrics is one of the most important factors affecting on optical quality defects on machines. For example wear of the fabric edges, inadequate safety guidance, incalculable change in the mechanical properties like tensile strength and elongation and other properties.

The narrow fabric (tape width) is affected by other factors like from warp direction as weft yarn tension and weft delivery length and from the weft direction as warp yarn tension as revealed in figure (1-1).

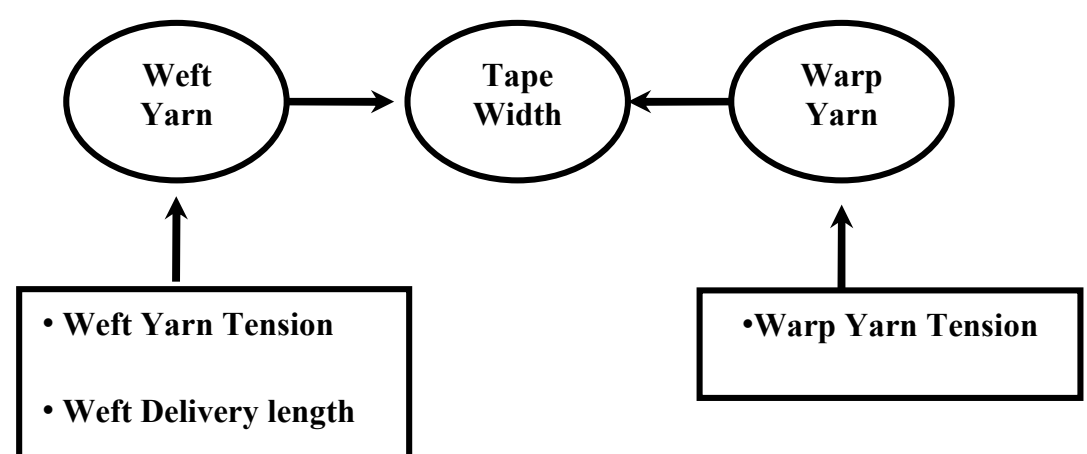

Figure (1-1): Effect of weft yarn and warp yarn on the tape width. 
C.R. CRORK and P.W. FOSTER studied the ballistic performance of narrow fabric and compared to that of wider fabric panels. It was found that the performance of narrow fabrics was highly sensitive to change $s$ in fabric specifications (2). Narrow knitted fabrics are made on a few needles on a multiknit machine, either filling or warp -knitting machines. One of the more important types of narrow knitted fabrics are knit elastics knit elastics account for 35-40 percent of the narrow elastic market and used in underwear, running shorts ,fleece are warp knit narrow fabrics(3)

For many fields of application, narrow fabrics are the so-called "golden link" within functional textiles, sometimes without even being noticeable. This is especially true in the case of smart clothes where narrow fabrics are used to provide communication links between the different electronic components within the garment. Other fields of application include automotive, aviation, transportation in general, medicine, safety, and sports and recreation. The aim of this research is the reduction of fluctuations in tape width by appropriate measures 5\%: $2 \%$. The Methodology of research: depends on the experimental and analytical approach, walkthrough and working steps, theoretical and experimental analysis of influence parameters on the tape width. Technical Derivation and technological measures to reduce the variability of tape width.

Developing a method for on-line monitoring and regulation of tape width during production as shown in figure (1-2):

Keyence line sensor 1s-7070 MR.

-Max Width Measuring $70 \mathrm{~mm}$.

-measuring 1.2 KHz frequency (4).
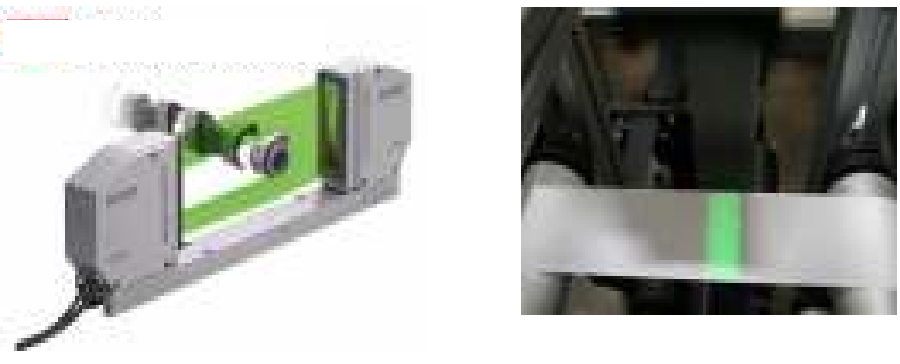

Figure (1-2): Keyence line sensor is $-\mathbf{7 0 7 0} \mathrm{MR}$ 


\section{2-Problem of Research:}

Narrow fabrics are generally considered as any textile fabric not exceeding 45 centimeters in width. Therefore narrow fabrics include any trimming, elastic, tape, ribbon, lace, cording etc.

Narrow fabrics are used for different applications in many industries and are most often used in the garments and home furnishing industry. They also find application in the marine and automotive industry and are also used for medical and safety purposes (5). Thus, Narrow fabric sector is the one of most important sectors of the textile industry and mostly employed in many fields. The quality of the tape plays a very vital role and is directly influenced by the elimination of the fluctuations in the tape width. These fluctuations are the problems faced by all the manufacturers of the narrow fabrics and cause the following problems as shown in figure (1-3).

1- The fabric edges of the clothes

2-Inadequate safety guidance

3-Unkalkulierbare changes the mechanical properties of tensile strength and elongation.

4-Optical quality defects on machines.

5-This is problem in companies which industrial narrow fabric.
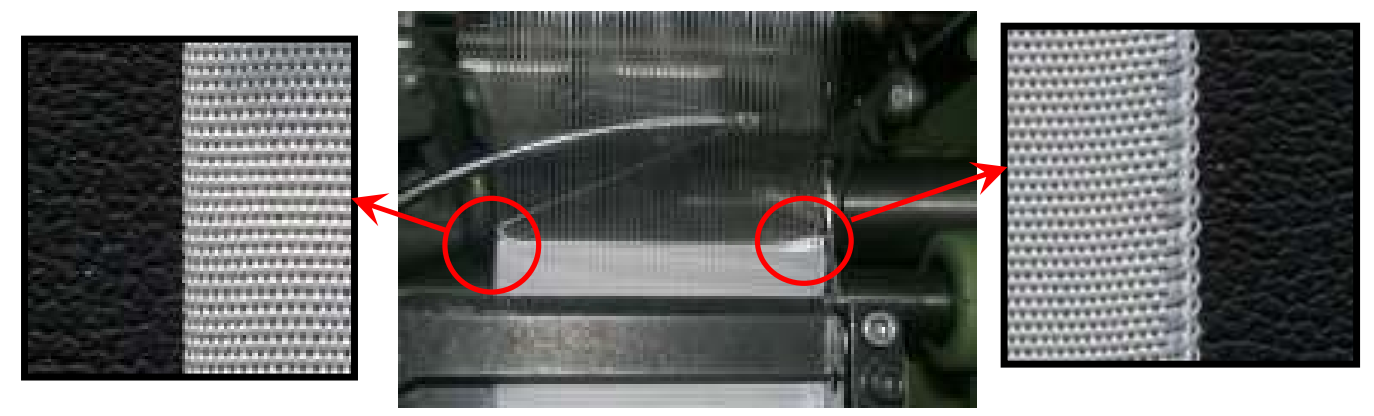

Figure (1-3): Tape width fluctuations 
ב Improving Production Textile Tapes On Needle Narrow Weave Machines

3 - OBJECTIVES OF RESEARCH:

1- To study the Weft Delivery Length as an effect property of Tape Width.

2- To study the Weft Yarn Tension as an effect property of Tape Width.

3- To study the warp Yarn Tension as an effect property of Tape Width.

\section{4-FACTORS EXAMINED THROUGH THE RESEARCH}

\section{4-1: Constant Specifications:}

4-1-1: Warp Material: (polyamide 6.6) - 67 dtex.

4-1-2: Weft material: (polyamide 6.6) - 67 dtex.

4-1-3: Machine: Needle narrow weave machine (NFRQ).

\section{4-2: Variable Specifications:}

\section{4-2-1: Weft Yarn Direction.}

4-2-1-1: Weft yarn tension.

4-2-1-2: Weft Delivery length.

\section{4-2-2: Warp Yarn Direction.}

4-2-2-1: warp yarn tension.

\section{5- RESULTS \& DISCUSSION}

\section{5-1: Relationship between The average warp yarn tension (cN) and Tape width (mm).}

Figure (1-5) shows Relationship between the average warp yarn tension $(\mathrm{cN})$ and tape width $(\mathrm{mm})$.

When the average warp yarn tension increases, the width tape also decreases. This implies that there exists an inverse relationship between the average warp yarn tension and tape width. Through the following in Equation (1).

$$
\mathrm{Y}=50.6-0.03 \mathrm{X} \quad \mathrm{r}=-0.9 \quad \text { Equation }(1)
$$


When the average warp yarn tension is increased by increasing the weight of gravity on the warp beam, it leads to the decrease the tape width as figure (1-4). It is attributed to the decrease the average warp yarn tension and this will lead to increase warp crimp and thus increase the width tape.

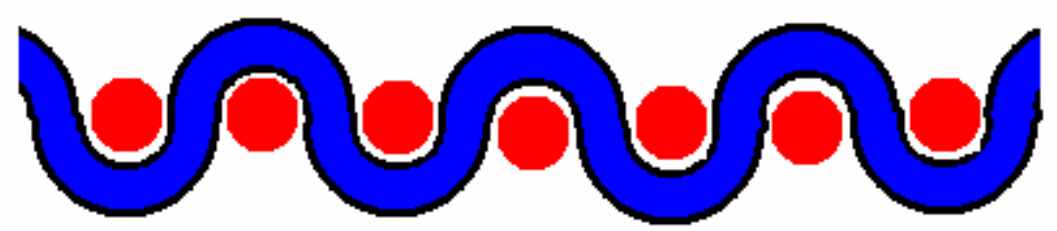

O Warp OWeft
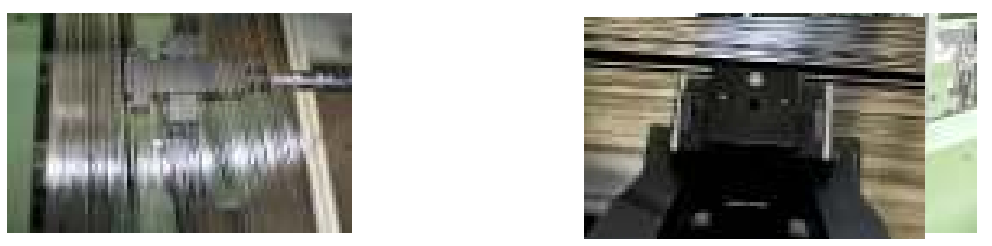

Figure (1-4): Tension measurement in warp and Cross section of warp and weft

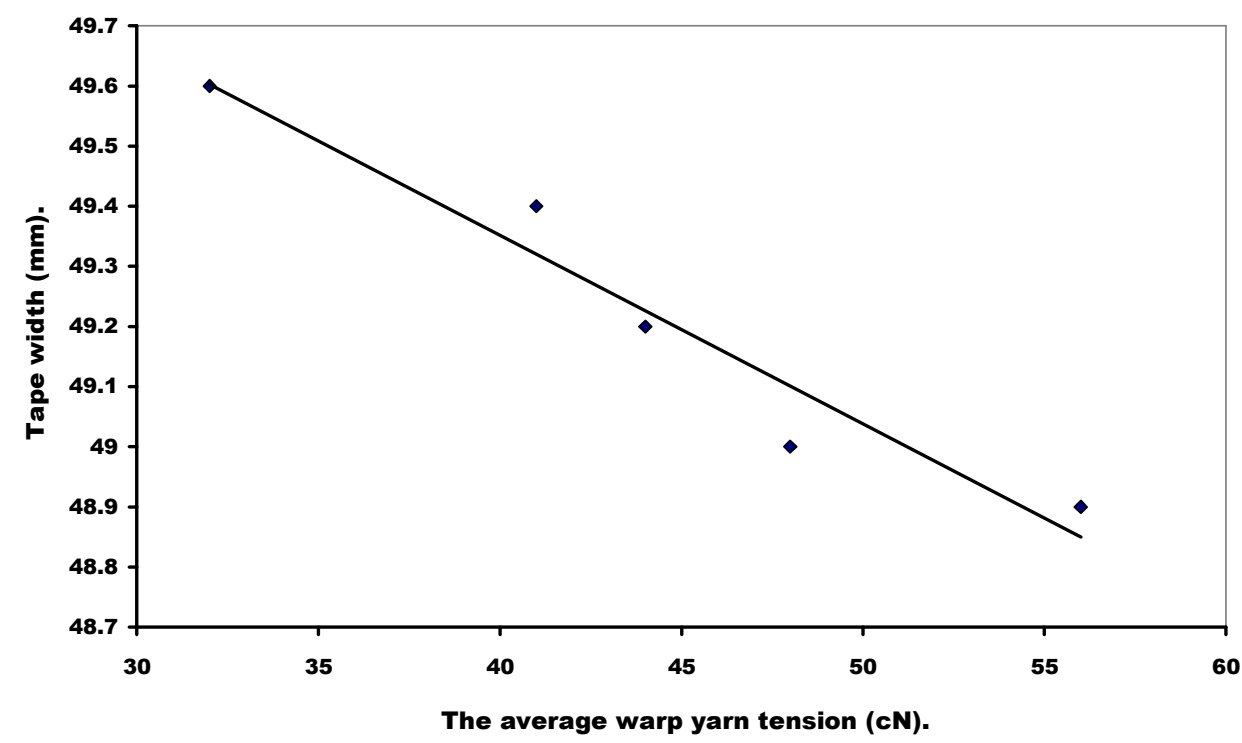

Figure (1-5): Relationship between the average warp yarn tension $(\mathrm{cN})$ and tape width. 


\section{5-2: Comparison between the weft delivery length (m.min- 1) and tape width $(\mathrm{mm})$.}

Figure (1-6) shows Relationship between the weft delivery length (m.min-1) and tape width (mm).

When the average weft delivery length increases, the width tape also increases. A direct relationship is found between the weft delivery length and tape width. Through the following in Equation (1).

$$
\begin{array}{lll}
\mathrm{Y}=7.22+0.63 \mathrm{X} & \mathrm{r}=0.96 \quad \text { Equation (1). }
\end{array}
$$

Width tape $=$ the weft delivery length - weft crimp.

Since the amount weft crimp is fixed, this will to increase the weft delivery length and ultimately increase the width tape also.

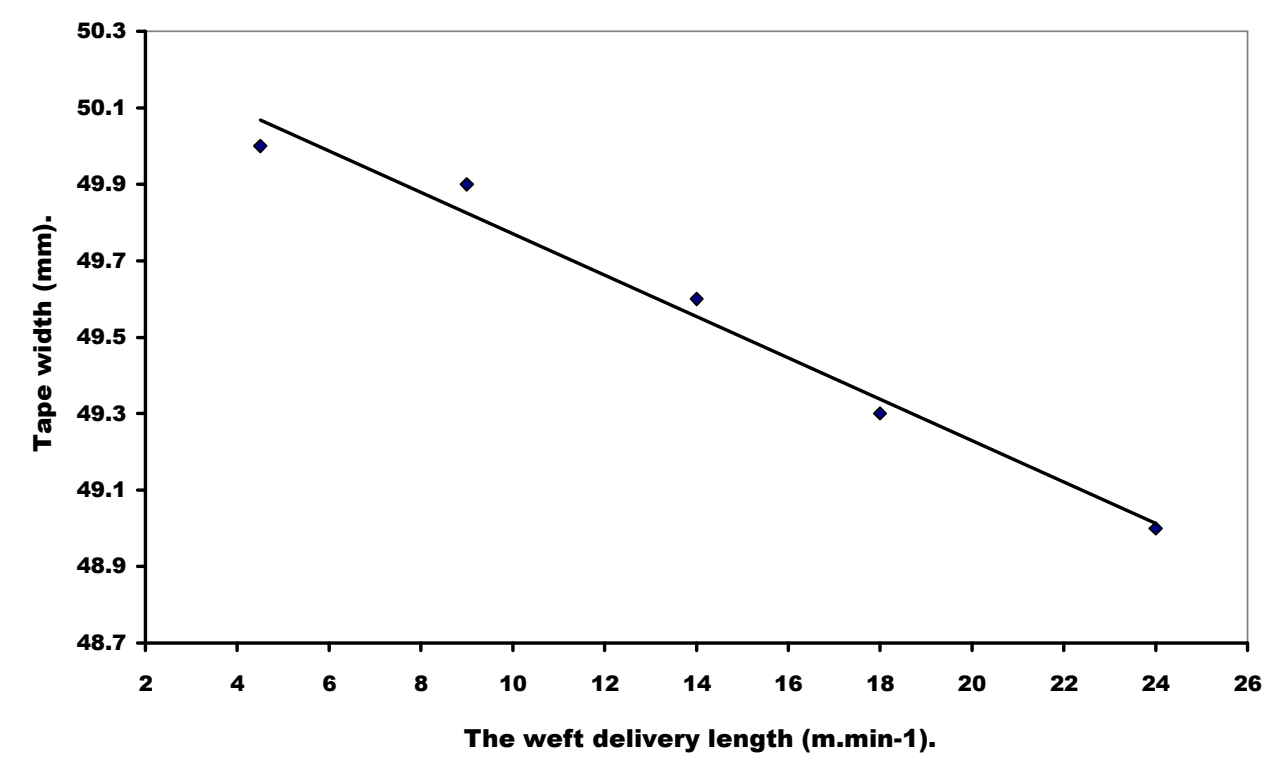

Figure(1-6): Relationship between The weft delivery length (m.min-1) and tape width (mm). 


\section{5-3: Comparison Between the average weft yarn tension (cN) and Tape width $(\mathrm{mm})$.}

Figure (1-7) shows Relationship between the average weft yarn tension $(\mathrm{cN})$ and Tape width $(\mathrm{mm})$.

When the average weft yarn tension increases, there is a decrease in width tape. Through the following in Equation (1).

$$
\mathrm{Y}=50.3-0.05 \mathrm{X}
$$$$
\mathrm{r}=-0.98
$$

Equation (1).

An inverse relationship is considered to be present between the average weft yarn tension and tape width. When the average warp yarn tension increase, attributed to increase warp crimp, this will decrease the weft crimp and thus cause the decrease in the tape width.

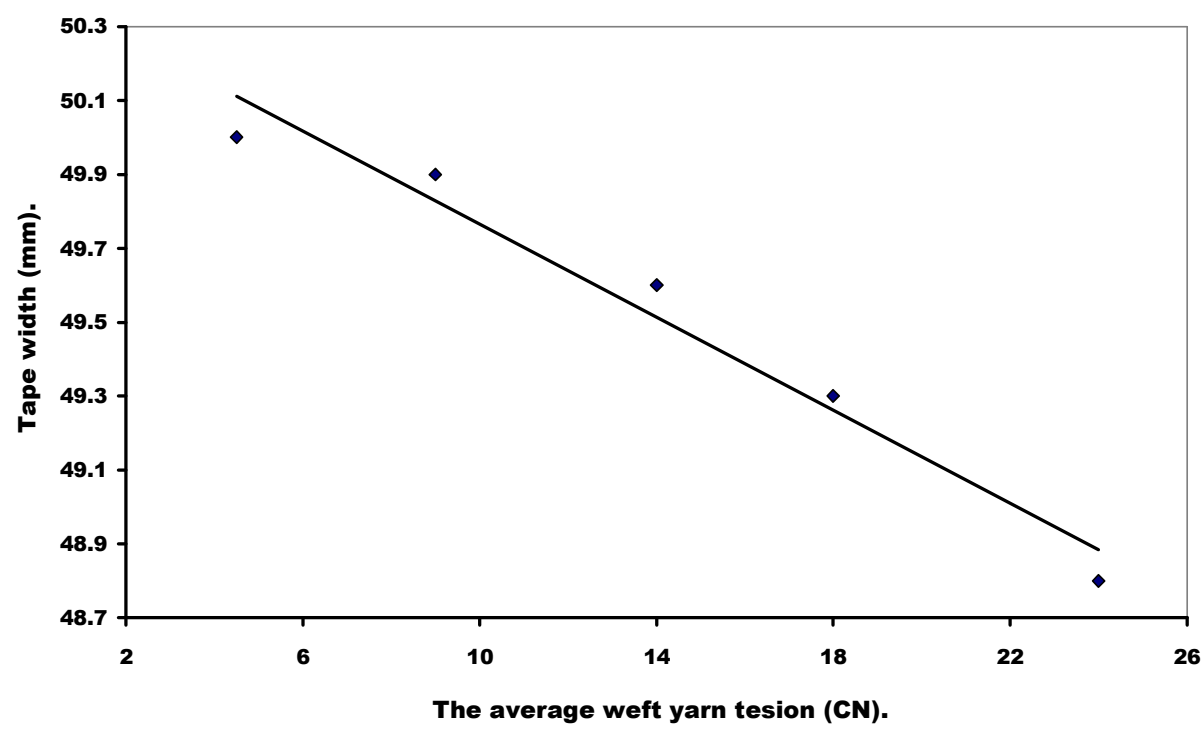

Figure(1-7): Relationship between The average weft yarn tension (cN) and Tape width(mm). 


\section{5-4: Comparison Between Machine speed (min-1) and Tape width (mm).}

Figure (1-8): shows the comparison between Machine speed (min-1) and Tape width (mm). When Machine speed increases, the Tape width also increases which shows a direct relationship. Through the following in equation (1).

$$
\mathrm{Y}=49.2+0.0009 \mathrm{X} \quad \mathrm{r}=0.99 \quad \text { Equation (1). }
$$

But this result reveals that the machine is incorrectly set because with the increase in the machine speed the tape width should not change, this implies that this result is due to a defect on a weft delivery.

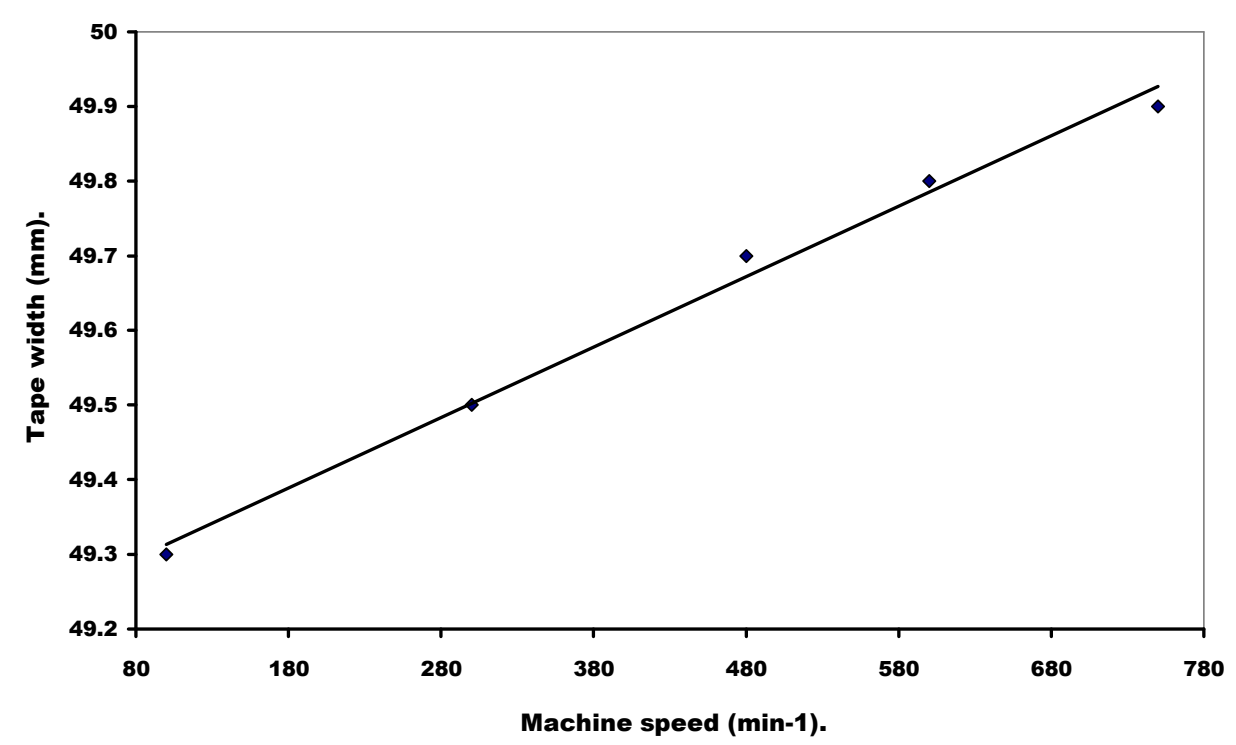

Figure (1-8): Relationship between Machine speed (min-1) and Tape width $(\mathrm{mm})$.

Figure (1-9) shows the relationship between the crank shaft rotation angle machine (min-1) and warp yarn tension $(\mathrm{cN})$ and weft yarn tension (cN). It is found that fixed relationship between the crank shaft rotation angle Machine and warp yarn tension.

Figure (1-10) shows the relationship between the crank shaft rotation angle machine (min-1) and warp yarn tension $(\mathrm{cN})$ and weft yarn tension $(\mathrm{cN})$. It is found that fixed relationship between the crank shaft rotation 
angle machine and weft yarn tension. This result showed that the machine is working properly. By changing weft delivery RIEMCHENTRANSPORT by weft delivery FOUMISSEUR (6)

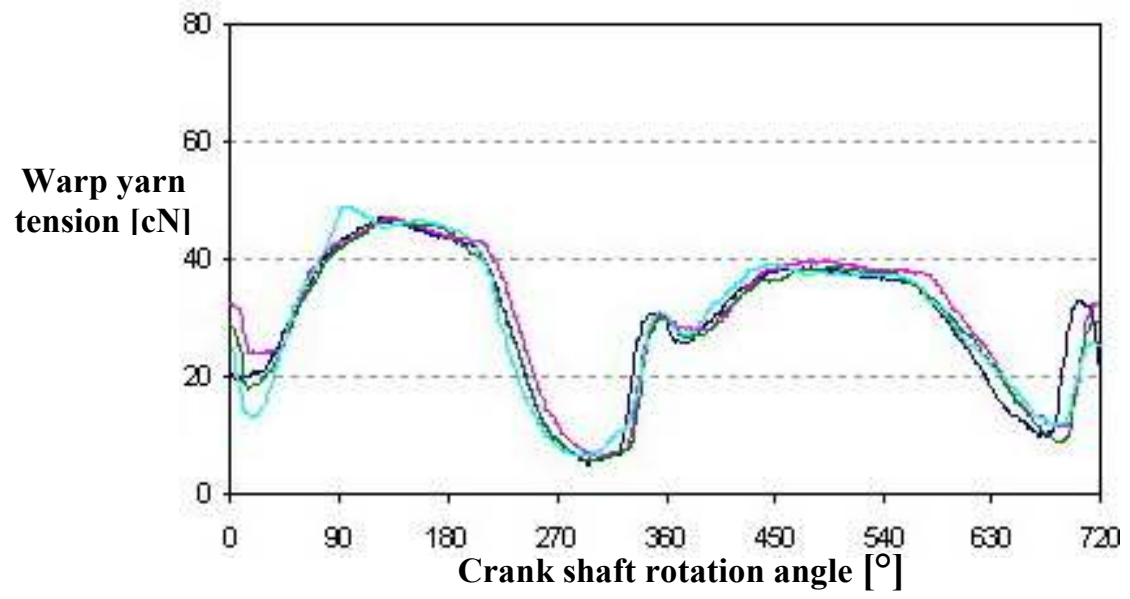

Figure (1-9): Relationship between crank shaft rotation angle and warp yarn tension $(\mathrm{cN})$

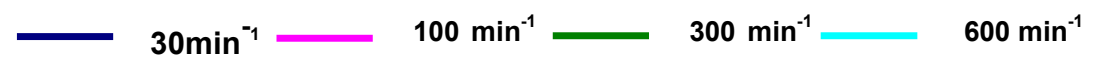

Figure(1-10): Relationship between crank shaft rotation angle (min-1) and weft yarn tension $(\mathrm{cN})$

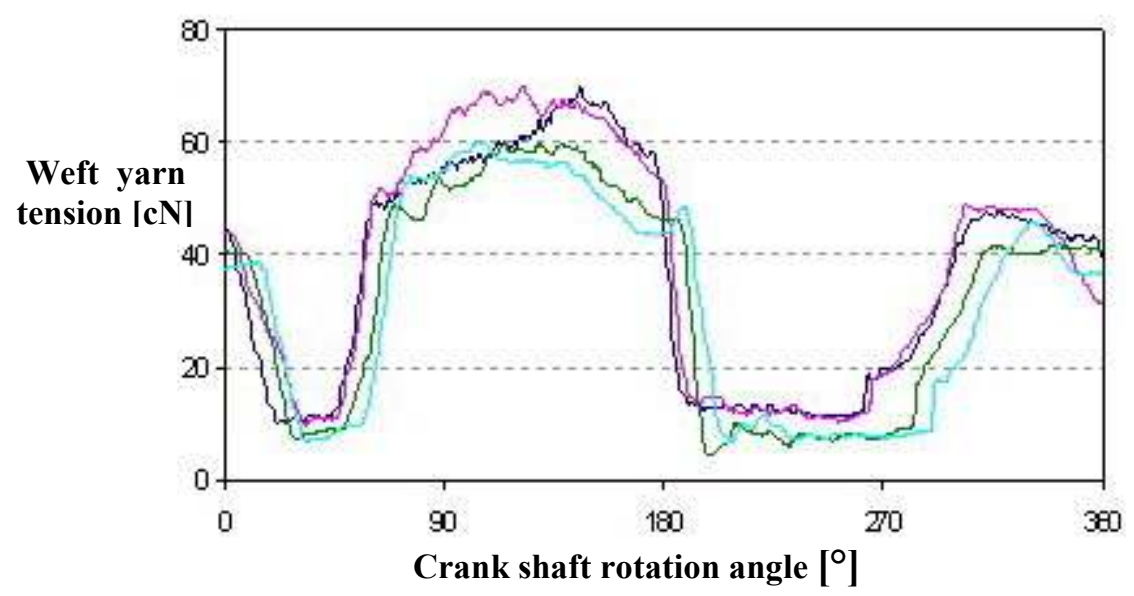

Figure (1-11): Relationship between crank shaft rotation angle and warp yarn tension $(\mathrm{cN})$. 
$30 \mathrm{~min}^{-1}$

$100 \mathrm{~min}^{-1}$

$300 \min ^{-1}$

$600 \min ^{-1}$

Figure(1-12): Relationship between crank shaft rotation angle (min-1) and weft yarn tension $(\mathrm{cN})$.

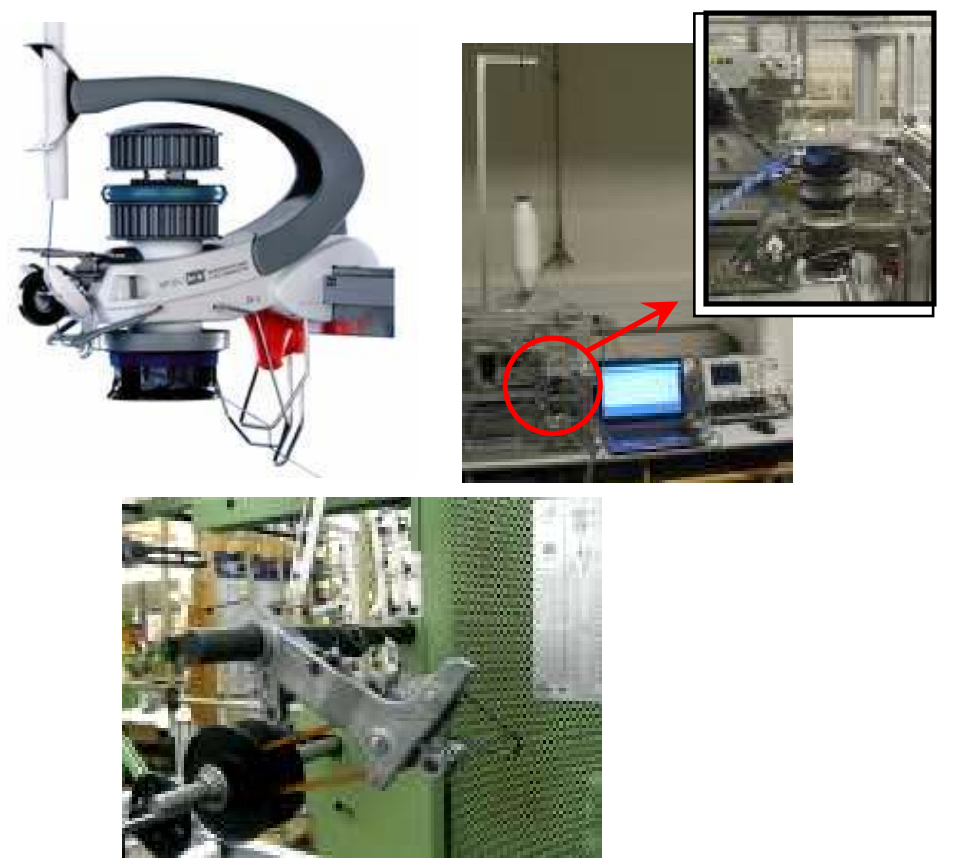

Figure( 1-13): weft feeder (Foumisseur) and ( Riemchentransport ). 


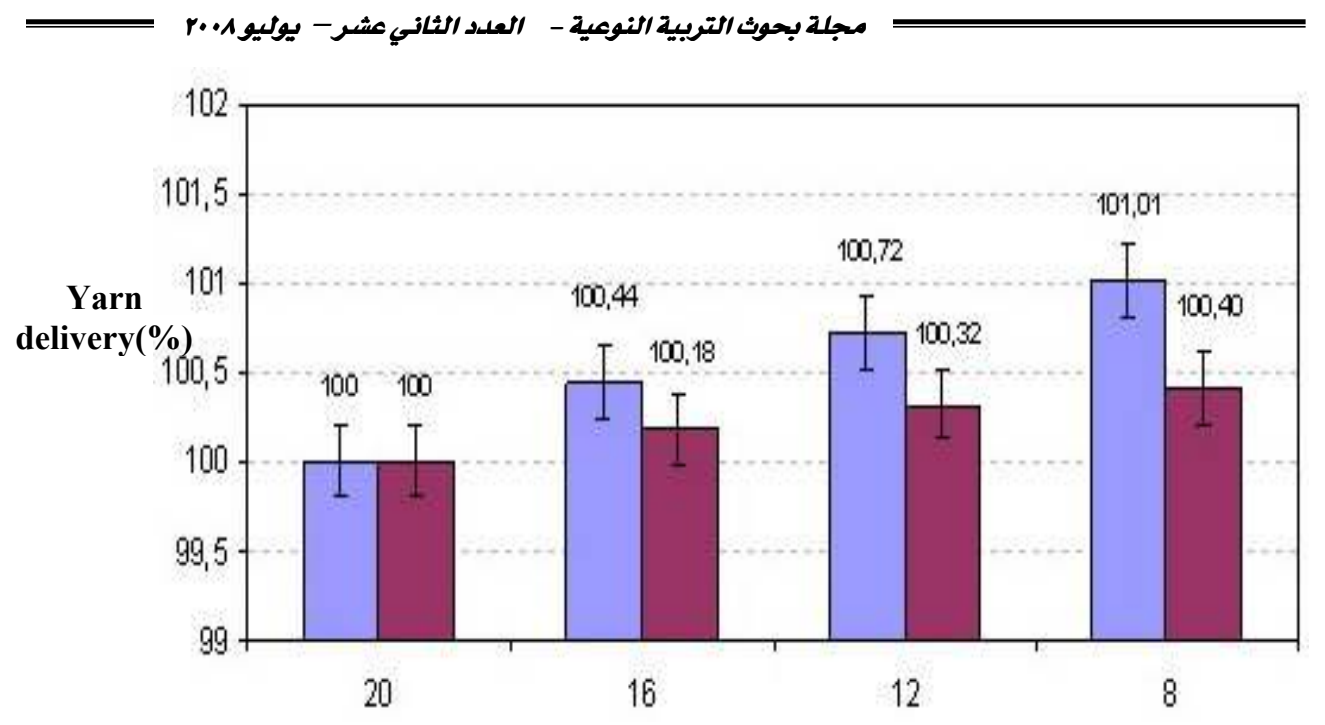

Figure( 1-14): Comparison between feeding delivery tension $(\mathrm{cN})$ and Yarn delivery $(\%)$.

Feeding delivery tension (cN)

1- RIEMCHENTRANSPORT

2- FOUMISSEUR

\section{7- REFERENCES:}

1-SRBEECH , C A FARNFLELD., P WHORTON , J A WILKINS,-Textile Terms and Definitions-Textile Institute-London-Eighth Edition-Year:1988, page : 165 .

2-C.R. CORK, P.W.FOSTER, THE BALLISTIC PERFORMANCE OF NARROW FABRIC, industrial journal of Impact Engineering N:34 Year: (2007) Page; 495- 508.

3-Sara J. Kadolph , Anna L. Langford., Jane Saddler, -Lawa State University-Textiles-Seventh Edition-Macmillan Publishing Company-New York-Year:1993, Page :248.

4-Quelle: www.keyence.de

5-http://www.narrow-fabrics-manufacturers.com/textile-terms-3.

6- Quelle: www. memminger-iro.de 